\title{
Discussion on future cooperation of physicists in agriculture
}

The possibility of establishing a regular contact between physicists concerned in agriculture was discussed at the meeting ${ }^{1}$ ). Such a contact is believed to be highly desirable and of great value for the development of physics in agriculture. It should be international as the number of physicists active in agriculture is small and moreover similar problems occur in different countries.

Physics enters in agriculture in many fields so for instance in :

1 Physics of the soil and the lower airlayer. This includes agricultural meteorology, evaporation, soil mechanics, drainage, irrigation, trafficability, cultivation.

2 Control of environments of plants and farm animals.

3 Physiology of plants and farm animals. Biophysics is closely related to the subjects 2 and 3 .

4 Technology of agricultural products i.e. food technology, conservation of agricultural products, dairying technology, wood technology, manufacture of raw materials for other industries (as manufacture of furfural for plastics), properties and control of quality of products.

5 Construction of instruments for various applications.

6 Development and introduction of quantitative methods in agriculture and particularly in agricultural engineering.

Transfer of heat and transfer of mass (water vapour, carbon dioxide) are important processes in many of these fields and physicists carrying out research on quite different subjects could benefit from a meeting in which one of these basic phenomena is discussed. It was, however, preferred to discuss a definite subject of outstanding importance at a future meeting, as had been done this time. It was further decided to leave the selection of the subject to the persons who will organize the future meeting.

Emphasis was lead on the necessity of a close cooperation with biologists and agronomists. They should be invited to any future meeting between physicists just as the physicist is invited to a meeting of e.g. phytopathologists.

Der Physiker muss quantitative Methoden entwickeln, die auf landwirtschaftliche Probleme Anwendung finden können. Eine besondere Beachtung muss dabei der Biometrie und der Pflanzenphysiologie geschenkt werden. Der Physiker müsste sich bemühen, immer eng mit Biologen und Landwirten zuzammenzuarbeiten, da dies eine wesentliche Voraussetzung für eine zielstrebige Anwendung physikalischer Gedankengänge und Messmethoden bei biophysikalischen Untersuchungen ist. Genau so wie der Physiker an Tagungen der Biologen, beispielsweise der Phytopathologie, teilnehmen soll, um dort an der Diskussion physikalischer Fragen beratend teilzunehmen, so sollten die an landwirtschaftlichen Problemen interessierten Physiker auch Biologen und Landwirte als Experten ihrer Fachrichtungen zu ihren Tagungen einladen.

1) Prof. S. TAKagI (Tokyo) suggested as a second main subject for the meeting : "Way to form firm cooperation among the worldwide searchers of agricultural physics". 
The question was then dicussed whether it should be advisable to establish a special body for the organization of contact between the physicists. It appeared that in some countries scientists might have some difficulty in obtaining funds to participate in a meeting unless it is backed by an official body of organization. In other countries person to person invitations are considered sufficient.

A certain amount of official backing is certainly necessary but it was thought that it should be left to the persons organizing the next meeting to decide to which extent this should go.

The common opinion was that the efficiency of the meeting would decrease if the number of participants would increase considerably.

Dr. SCHоFIELD speaking on behalf of the British participants, then offered to arrange a meeting of the present size (approx. 50 participants) in England, three years from now. This offer was unanimously accepted by acclamation. 